\title{
Characteristics of Motorcycle Ownership and Use of University Students in Malaysian and Indonesian Cities
}

\author{
Putranto, L.S. ${ }^{*}$, Prasetijo, J. ${ }^{2}$, and Setyarini, N.P.S.E. ${ }^{1}$
}

\begin{abstract}
Motorcycle ownership and use increased rapidly in Indonesian cities in recent years. People could not cope with severe congestion due to unsatisfactory public transport and uncontrolled land use delopment. This led to motorcycle use for almost any trip. However, in Malaysia motorcycles were mainly used for local short distance travel. In this paper the characteristics of motorcycle ownership and use of university students in Malaysian and Indonesian cities were discussed. A total of 398 university students in eight cities were asked to fill the questionnaires. They consist of general questions regarding their socio-economic background and travel habit along with 25 perceptional questions regarding affordability/ attractiveness of owning motorcycle and practicability/safety of motorcycle use. A variance based structural equation modelling called partial least square-path modelling (PLS-PM) was used for analysis. The results show that indicators explaining affordability and acceptability were exactly the same in Penang and combination of seven cities in Indonesia.
\end{abstract}

Keywords: Motorcycle ownership; motorcycle use; PLS-PM.

\section{Introduction}

In developing countries it is common that road and rail based infrastructure could not compete with rapid development of the cities. Cities in South East Asian Countries have long history of high motorcycle ownership and use to face such condition. Vietnam cities have suffered from very high proportion of motorcycle in general traffic (as high as $90 \%$ in their main cities) for many years. It has just happened in Indonesia in the last five years. In Indonesian cities, public was so desperate with severe congestion due to unsatisfactory public transport and uncontrolled land use development. Therefore, they tried to find their own way to maintain "acceptable" travel time by using motorcycle. This led to motorcycle use for almost any purpose and wide range of trip length in Indonesian cities. This was not the case in Malaysia, where motorcycles were mainly used for short distance casual travel in the neighbourhood area such as in the university area. This was found in aggregate level research (Malaysian state based research and Indonesian city based research) [1] . This paper is aimed to observe specifically student perception in motorcycle ownership and use in Indonesian and Malaysian cities in disaggregate (individual) level. Students were identified as one of important group of owners and users of motorcycles.

${ }^{1}$ Civil Engineering Department, Tarumanagara University, Л. S. Parman No 1 Grogol Jakarta 11440, INDONESIA

2 Civil Engineering Department, Universiti of Tun Hussein Onn, Beg Berkunci 101 Parit Raja. Batu Pahat. Johor West 86400, MALAYSIA* Corresponding author; e-mail: lexy_putranto@yahoo.co.id

Note: Discussion is expected before June, $1^{\text {st }} 2015$, and will be published in the "Civil Engineering Dimension" volume 17, number 2, September 2015.

Received 01 December 2013; revised 20 October 2014; accepted 13 December 2014.
The reason for selecting students in Medan, Palembang, Bandung, Surabaya, Denpasar, Mataram, Makassar, and Penang was to follow up previous research [1] and availability of research partner to conduct data collection.

\section{Previous Studies}

Putranto and Tantama [2] have conducted 24 hours traffic count in Bandung, Surabaya, and Mataram in Indonesia. In each city, two four lanes-two ways divided roads (4/2 D) and two six lanes-two ways divided $(6 / 2 \mathrm{D})$ road were observed in a normal working day. However, in Mataram no six lanes-two ways road was eligible for observation. Statistical tests showed that percentage of motorcycle in each city was significantly higher than in the Indonesia Highway Capacity Manual (IHCM) [3] reference value, whilst percentage of light vehicle and heavy vehicle in each city were significantly lower than in IHCM [3] reference values. Putranto and Setyarini [4] found similar results in Medan, Makassar, Denpasar, and Palembang.

The following literature reviews are used to justify the indicators of latent variables explaining motorcycle ownership and motorcycle use dimensions:

According to Putranto [5]:

- In a non-car owning household, the higher the number of household members, the higher the number of motorcycles.

- Surrounding the universities, the higher the number of students (number of household members aged $>16$ years old) the higher the number of motorcycles. 
- The higher the wealth level the lower the number of motorcycles.

- The number of motorcycles produced was usually similar to the number sold domestically. Some production was exported.

- The percentage of exported motorcycles reached a peak (16\%) in 1998 due to low domestic market absorption. Normally, exported motorcycles account for fewer than $10 \%$ of total production.

According to Kurniawan [6]:

- In the fast lanes, motorcycles tended to flow in the middle sector (between two lanes).

- In the frontage road, motorcycles were distributed evenly in all sectors

According to Lin et al. [7]:

- Past motorcycle crash history, number of riding days, average riding distance, risk-taking level, alcohol consumption, and traffic violations were all significantly associated with an increased risk of being involved in a crash.

- Increasing age, riding experience, and automobile licensure were related to a decreased risk of crashing.

- Helmet use was not independently related to the risk of crashing.

According to Tuan and Shimizu [8]:

- In Hanoi, Vietnam, increases in number of workers or students, motorcycle price, income, and previous transactions significantly influence current motorcycle ownership decisions.

- Sufficient high taxes imposed on motorcycle users could be effective in controlling the ownership.

According to Putranto et al. [9]):

- Mature motorcycle rider tends to be more considerate compares to novice rider before a ride (riding preparation) and during the ride.

- Low income motorcycle rider tends to violate traffic rule more often compares to higher income motorcycle rider.

- Helmet usage was related to other responsible behaviour such as posession of driver's license, low accident, and low traffic rule violation.

According to Manan and Varhelyi [10]:

- The majority of motorcycle related fatal accidents in Malaysia involved 16 to 20 years old riders.

- $75 \%$ of the motorcyclists wore helmets, and $35 \%$ did not have proper licences.

According to Chiu et al. [11]:

- After the implementation of motorcycle helmet law in Taiwan in 1 June 1997, the number of motorcycle-related head injuries decreased by $33 \%$.

- Full helmets were found to be safer than halfshell helmets.

According to Swaddhiwudhipong et al. [12]:

- Two years after motorcycle rider education in Thailand, the residence of intervention villages (in which motorcycle rider education were provided) were more likely to have valid license than those in the control villages. The proportion of riders who always and often wore helmet were also higher in the intervention villages than in the control villages.

According to Li et al. [13]:

- In a survey in China, 75,949 riders and 17,230 passengers were observed. A large proportion of both riders and passengers $(34 \%$ and $71 \%$, respectively) did not wear helmet, or did not have their helmet fastened (34\% and 14\% respectively).

- Proper helmet usage rates were lower among male drivers, younger people, on secondary streets, and during the evenings, and weekends.

- The majority (90\%) of the 2325 drivers interviewed acknowledged the benefits of helmet wearing, but $72 \%$ reported that helmets are not always comfortable, and only $20 \%$ said they would wear a helmet for preventive purposes.

According to French et al. [14]:

- In USA, helmet laws have the most significant effect on both non-fatal and fatal injuries.

- Mandatory rider education programs and speed limits on rural inter-states significantly impact non-fatal injuries.

According to Chang and Yeh [15]:

- In Taiwan, young riders, particularly young female riders with the least riding experience, at increased risk of having an accident. These additional factors may be poor driving skills and less experience, all of which may result from the slack motorcycle licensing system.

- There should be increased emphasis on the necessity of providing appropriate training and a lower risk environment for novice riders.

According to Rosenbloom et al. [16]:

- In hazard perception test in Israel, performance of 50 male riders with and without a motorcycle license was observed in order to generalize results. A video-based test, measuring reaction times to traffic scenes, was administered to these two groups of riders.

- Participants with a motorcycle license performed better than participants without a motorcycle license.

According to Wong et al. [17]:

- This study adopts Structural Equation Modelling (SEM) to analyze data collected from 683 young motorcyclists aged between 18 and 28 in Taiwan.

- The results conclude three primary personality traits of young motorcyclists, namely sensation seeking, amiability, and impatience.

- While amiable riders represent a group of relatively mature and safe riders, the sensationseeking riders are extremely self-confident, and comfortable with unsafe riding. Meanwhile, the sensation-seeking ones also are highly aware of 
traffic conditions, which may lower the chances of getting into an accident, but the accident could be extremely severe if it ever occurs. Impatient riders, having low riding confidence, and traffic awareness deficiency, however, their fear of an accident leads them to fail to observe surrounding traffic conditions.

\section{Research Method}

Questionnaires were distributed to university students in Penang, Malaysia and seven cities in Indonesia (Medan, Palembang, Bandung, Surabaya, Denpasar, Mataram, Makassar) to know their perception on motorcycle ownership and motorcycle use. The questionnaires consisted of general data and perceptional questions. It should be noted that the purpose of indicator coding was to facilitate convinient modelling using Smart-PLS freeware [18]. The first three digits express the name of the construct, e.g. AFF stands for AFFordability. After an underscore, there is abbreviation consist of combination of letters and number expressing indicator explanation and number, e.g. AFF_PRI1 means indicator number 1 regarding motorcycle cheap PRIce under affordability construct. In case of two digits indicator number, the abbreviation should be reduced into two letters to keep the maximum length of indicator name to be eight digits, e.g. PRA_PA11 means indicator number 11 explaning easiness of motorcycle PArking under PRActicability construct. All together, there are 25 indicators. There are no missing indicator number, but in some cases the number is not in order, because during the analysis there were some regrouping process of indicators into more appropriate construct.

Questionnaires-general data are as follows

- Name

- Gender $[15,16]$

- Enrollment year as a proxy of age $[5,7,9,10,13$, $15,17]$

- Age $[5,7,9,10,13,15,17]$

- Residensial type as a proxy of wealth level $[5,8]$

- Ownership of cars, motorcycles, and bicycles [5]

- Daily transport mode for campus trip [7]

- Daily transport mode for non-campus trip [7]

Questionnaires-Perceptions

- On motorcycle ownership:

- Affordability

- Motorcycle price is cheap (AFF_PRI1) [8]

- Purchasing scheme is flexible (AFF_FLE2) [5]

- Family financial condition allow the purchase (AFF-FIN3) [5,9]

- Government policy support affordability (AFF_GOV4) [5]

- Operational cost is affordable (AFF_OC25) [5]
- Acceptability

- Owning motorcycle improve self-esteem (ACC_SEL5) [17]

- Owning motorcycle increase the number of friends (ACC_FRI6) [17]

- Using motorcycle increase one's attractiveness (ATT_AT24 [17]

○ On motorcycle use:

- Practicability

- Practical for daily use (PRA_DAI7) [6]

- Reach destination faster (PRA_FAS8) [6]

- Use small parking space (PRA_GAP9) [6]

- Maintain daily schedule (PRA_SC10) [6]

- Easy to park (PRA_PA11) [6]

- Government support daily use (PRA_ GO12) [6]

- For various activities (PRA_AC13) [6]

- For various deliveries (PRA_DE14) [6]

- For all legal ages (PRA_AG15) [5,6,7,9,10]

- Easy to operate (PRA_EA16) [6]

- Despites its inconvenience during the rain, motorcycle is still practical to use (PRA RA17) [6]

- Safety

- Motorcycle is safe mode of transport (SAF_ SA18) [7,9,10]: Removed

- Helmet improves safety (SAF_HE19) [7,9, $10,11,13,14]$

- Bright Colour Outfit improves safety (SAF_ BO20) [9]

- Valid license guaranties safe ride (SAF_ LI21) [7,9,12]: Removed

- Mature riders are safer (SAF_MA22) [5,7, $9,10,11,13,15]$

- Training guaranties safe ride (SAF_TR23) $[12,14,15]$

Scale of the questionnaire was designed as follows: strongly disagree, disagree, neutral, agree, and strongly agree. Sample scope and size from several universities (Indonesia and Malaysia) are as follows:

- Insitut Teknologi Nasional (Itenas), Bandung, 50 undergraduate students

- Institut Teknologi 10 November (ITS), Surabaya, 59 undergraduate students

- Politeknik Negeri Medan (Poltek Medan), Medan, 50 vocatioal studies students

- Universitas Mataram (Unram), Mataram, 50 undergraduate students

- Universitas Hasanuddin (Unhas), Makasar, 47 undergraduate students

- Universitas Sriwijaya (Unsri), Palembang, 43 undergraduate students

- Universitas Udayana (Unud), Denpasar, 49 master students

- Universiti Sains Malaysia (USM), Pinang, 50 undergraduate students

Even though respondents from Universitas Udayana, Denpasar, were master students but only younger group of students were selected to satisfy similar age group with respondents from other univerasities. 
The analysis was carried out using variance based Structural Equation Modelling (SEM), i.e. Partial Least Square-Path Modelling (PLS-PM). The model is a combination of formative model and reflective model where Standardized Loading Factor (SLF) should be positive and more than 0.5. Formative models consist of three constructs, i.e. affordability, practicability, and safety. Reflective models consist of three constructs, i.e. acceptability, motorcycle ownership, and motorcycle use. A freeware called SmartPLS was used.

\section{Data Analysis}

Figures 1, 3, 5, 7, 9, 11, 13, 15, and 17 show the full model of Smart-PLS for combined seven universities in Indonesia, each of the seven universities in Indo- nesia and Universiti Sains Malaysia, respectively, while Figures 2, 4, 6, 8, 10, 12, 14, 16, and 18 show the final model of Smart-PLS for the same. Final models were found by deleting indicators with standardized loading factor (SLF) less than 0.5. The summary of these are shown in Table 1 . It can be seen that affordability of owning motorcycle in general can be explained by either cheap price of motorcycle and financial capability to purchase motorcycle. In general acceptability of owning motorcycle can be expressed by higher self-esteem, more friends, and higher attractiveness of a person owning motorcycle. Practicability of using motorcycle in general can be explained by its ability to shorten travel time during congestion. Lastly, the safety of using motorcycle in general can be explained by maturity of the rider.

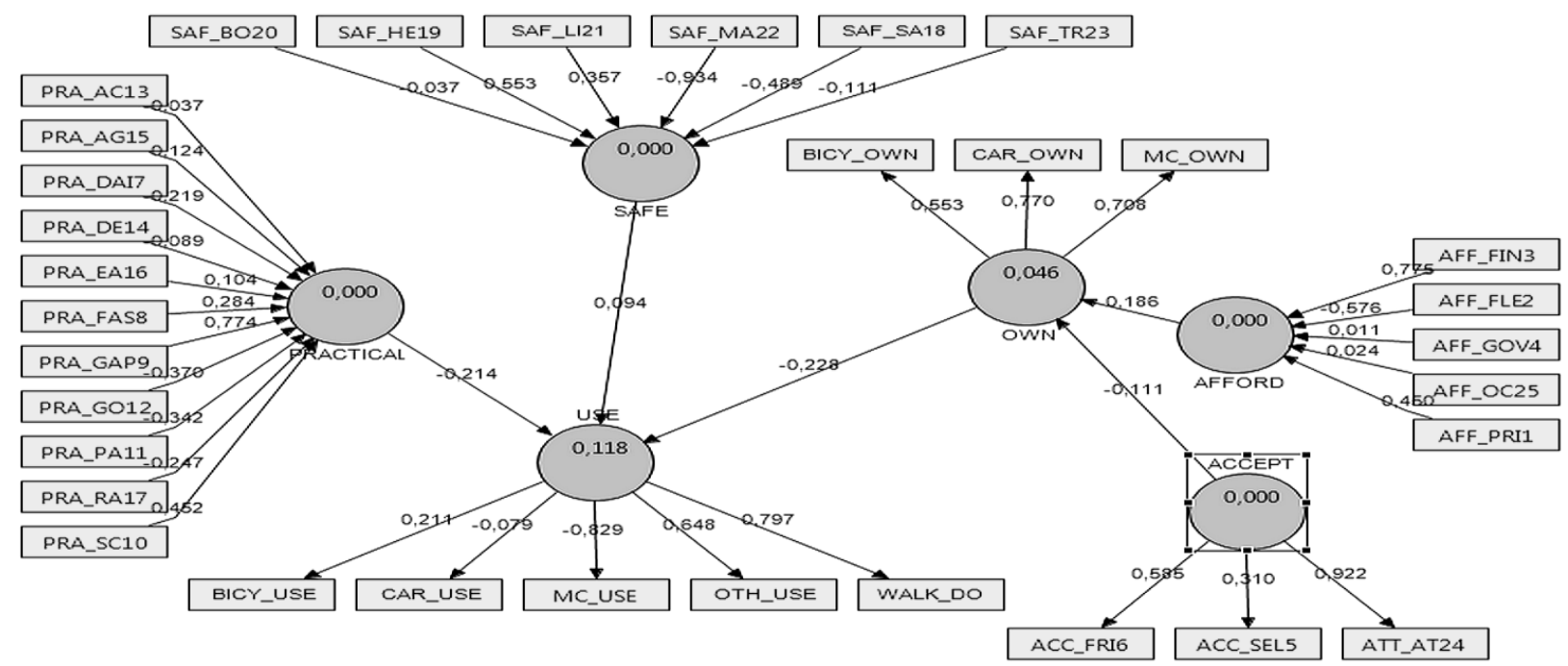

Figure 1. Smart PLS Full Model for Seven Indonesian Universities

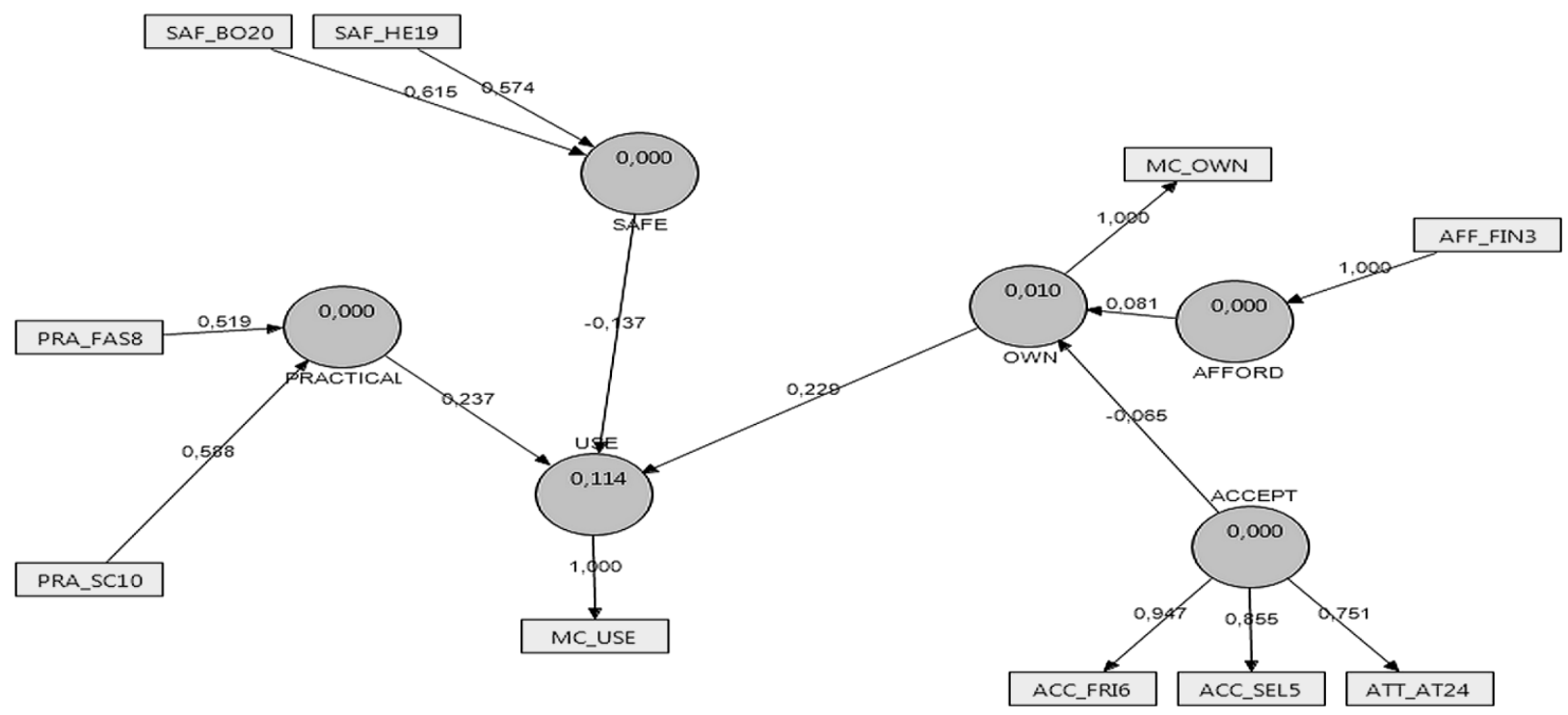

Figure 2. Smart PLS Final Model for seven Indonesian Universities 


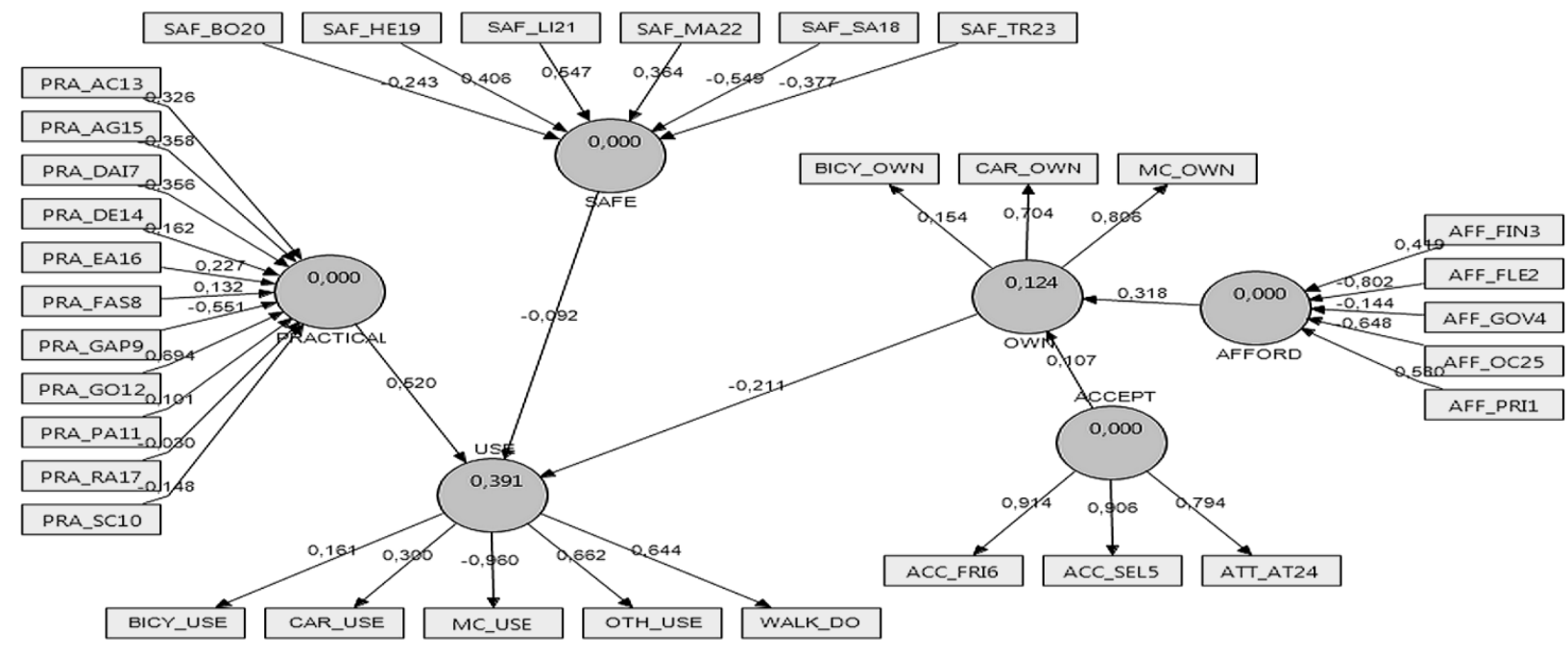

Figure 3. Smart PLS Full Model for Institut Teknologi Nasional (Itenas) Bandung

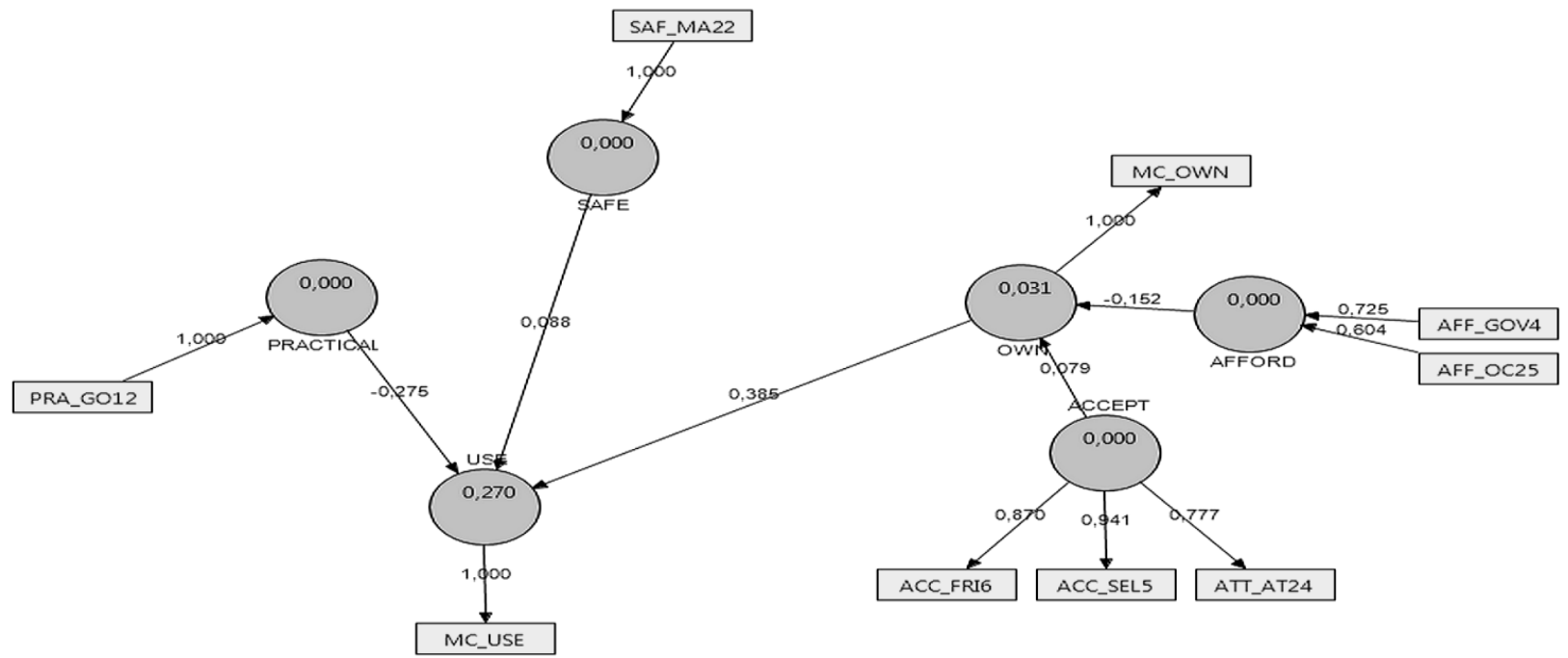

Figure 4. Smart PLS Final Model for Institut Teknologi Nasional (Itenas) Bandung

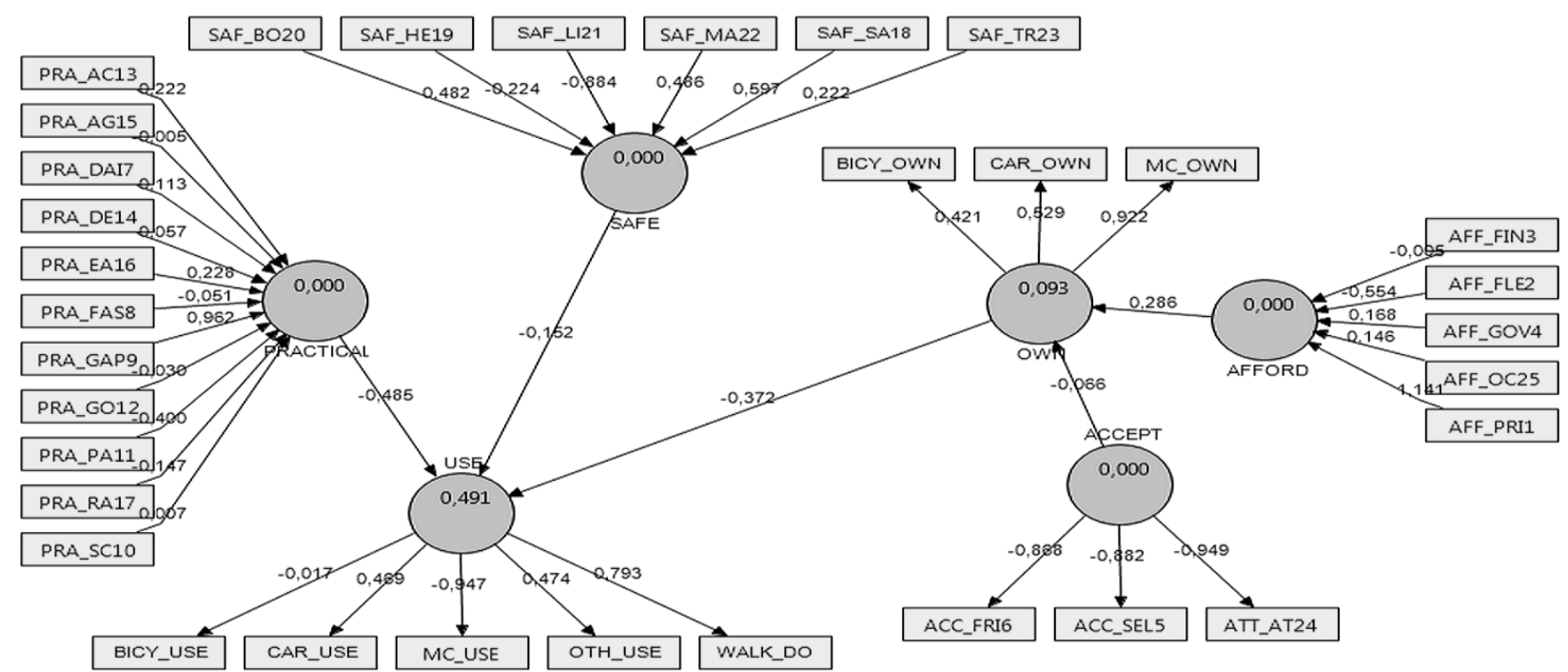

Figure 5. Smart PLS Full Model for Institut Teknologi Sepuluh November (ITS) Surabaya 


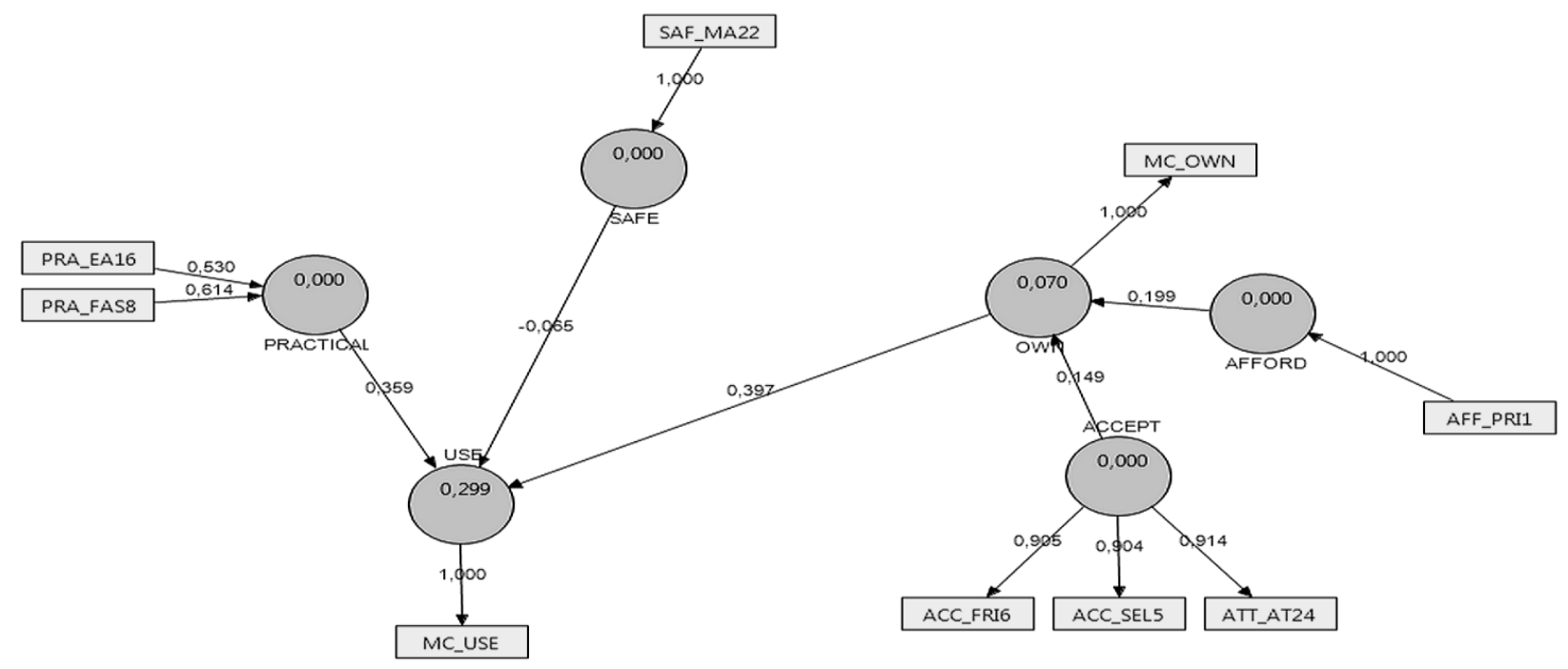

Figure 6. Smart PLS Final Model for Institut Teknologi Sepuluh November (ITS) Surabaya

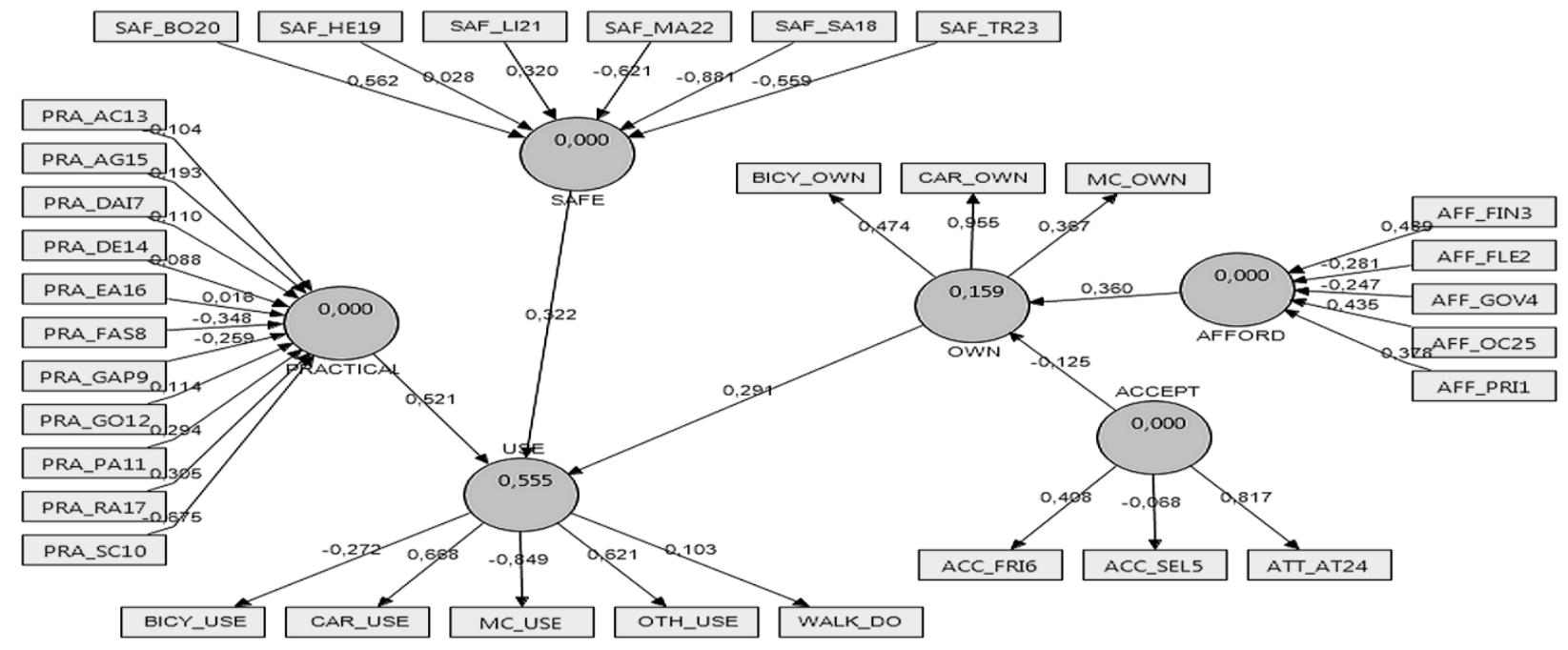

Figure 7. Smart PLS Full Model for Politeknik Negeri Medan (Poltek Medan)

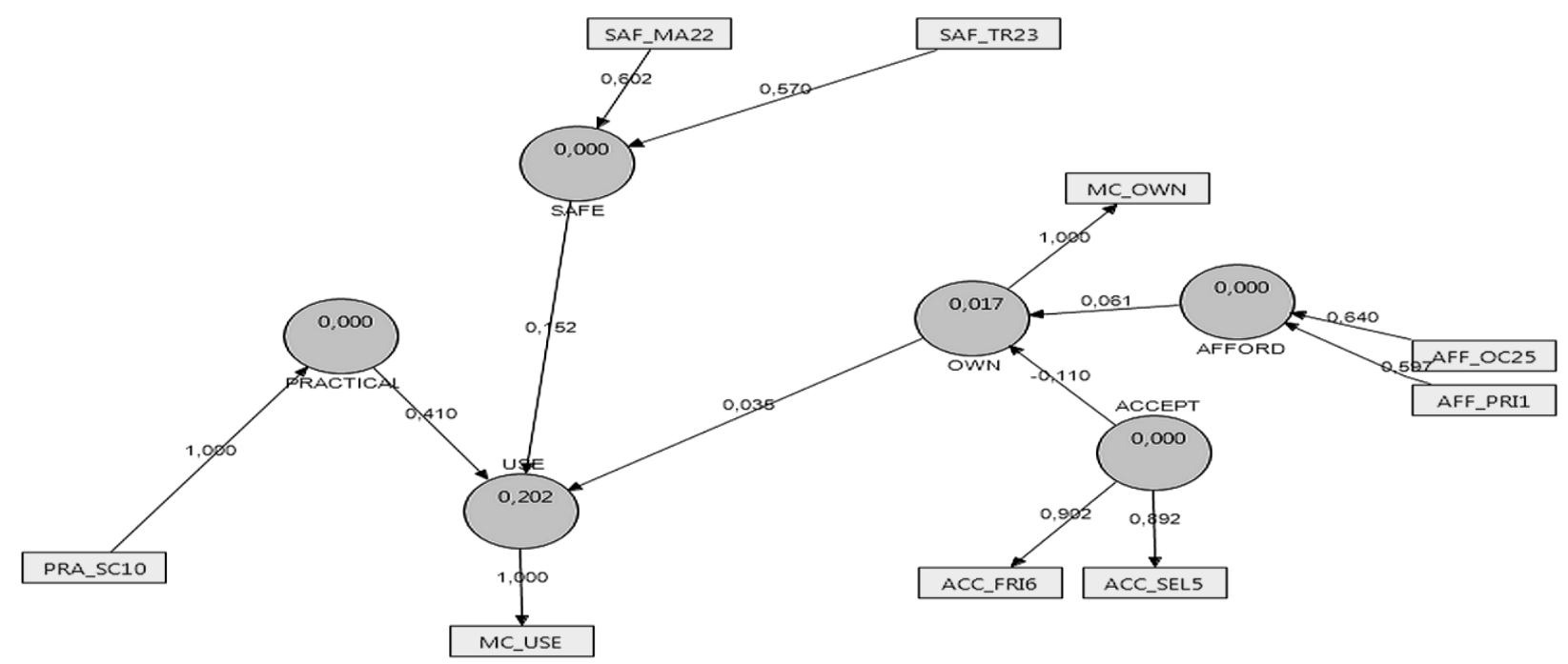

Figure 8. Smart PLS Final Model for Politeknik Negeri Medan (Poltek Medan) 


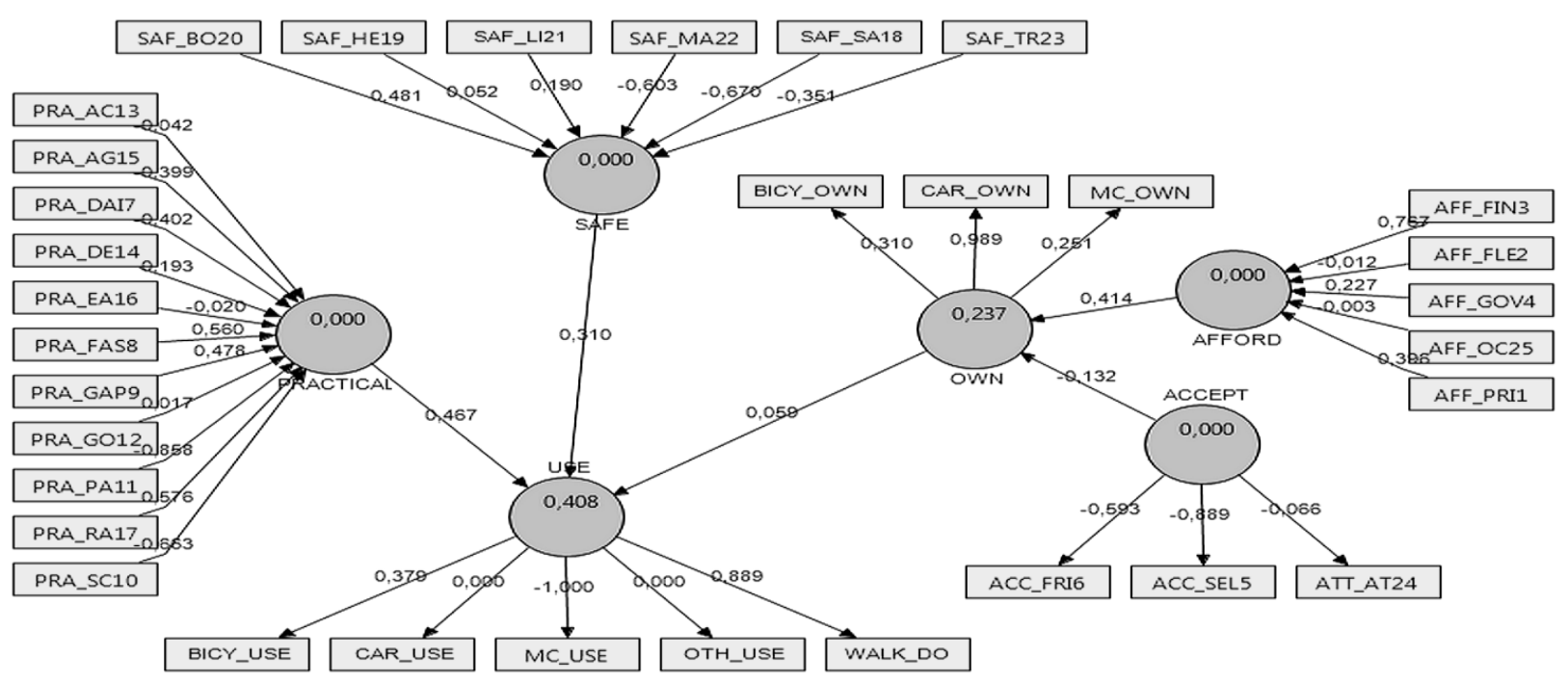

Figure 9. Smart PLS Full Model for Universitas Mataram (Unram)

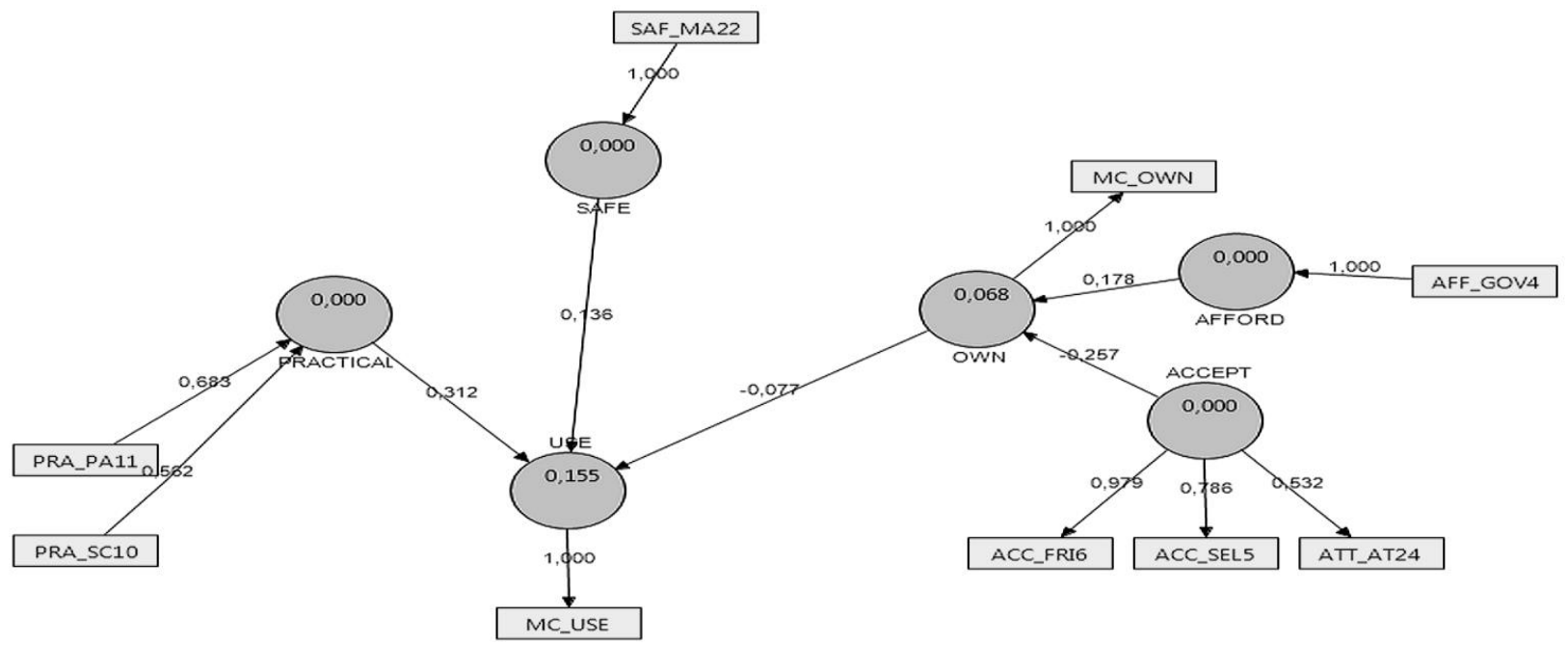

Figure 10. Smart PLS Final Model for Universitas Mataram (Unram)

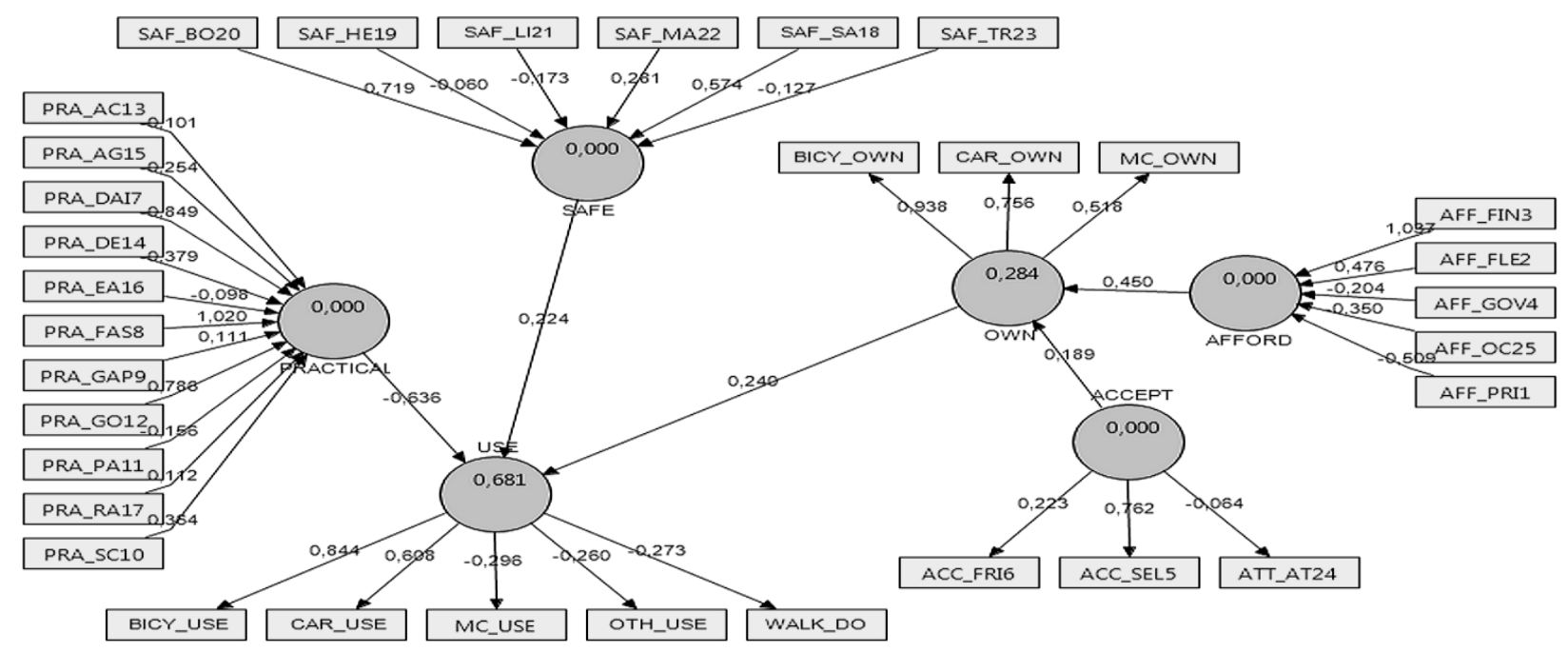

Figure 11. Smart PLS Full Model for Universitas Hasanuddin (Unhas) 


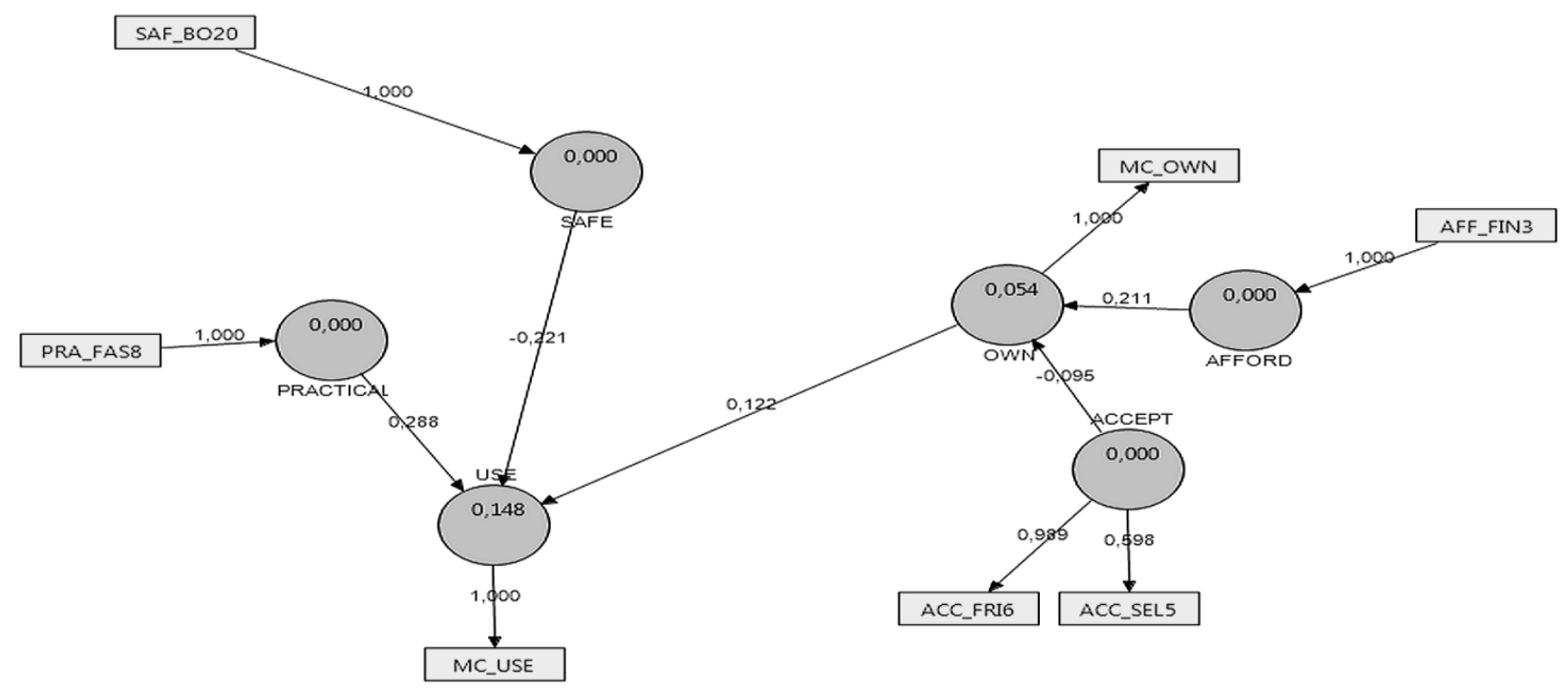

Figure 12. Smart PLS Final Model for Universitas Hasanuddin (Unhas)

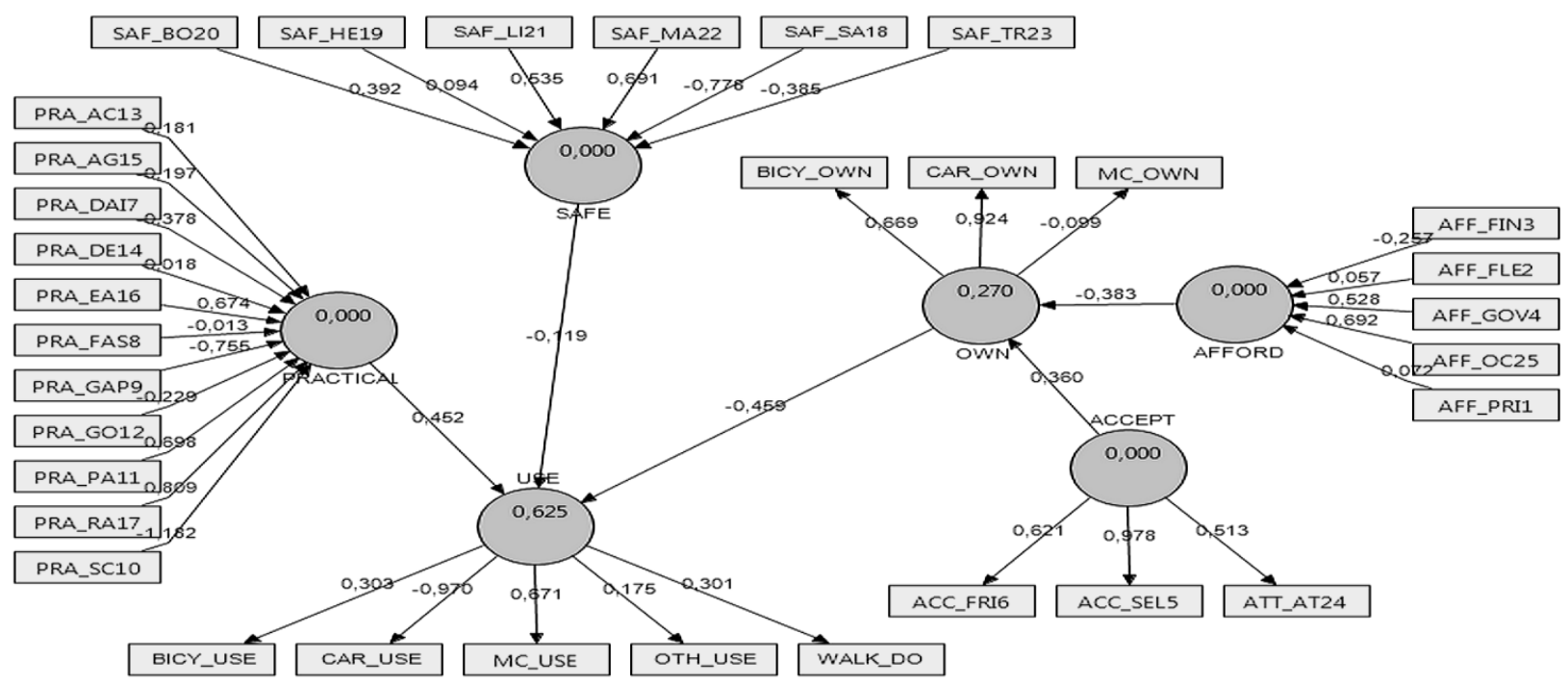

Figure 13. Smart PLS Full Model for Universitas Sriwijaya (Unsri)

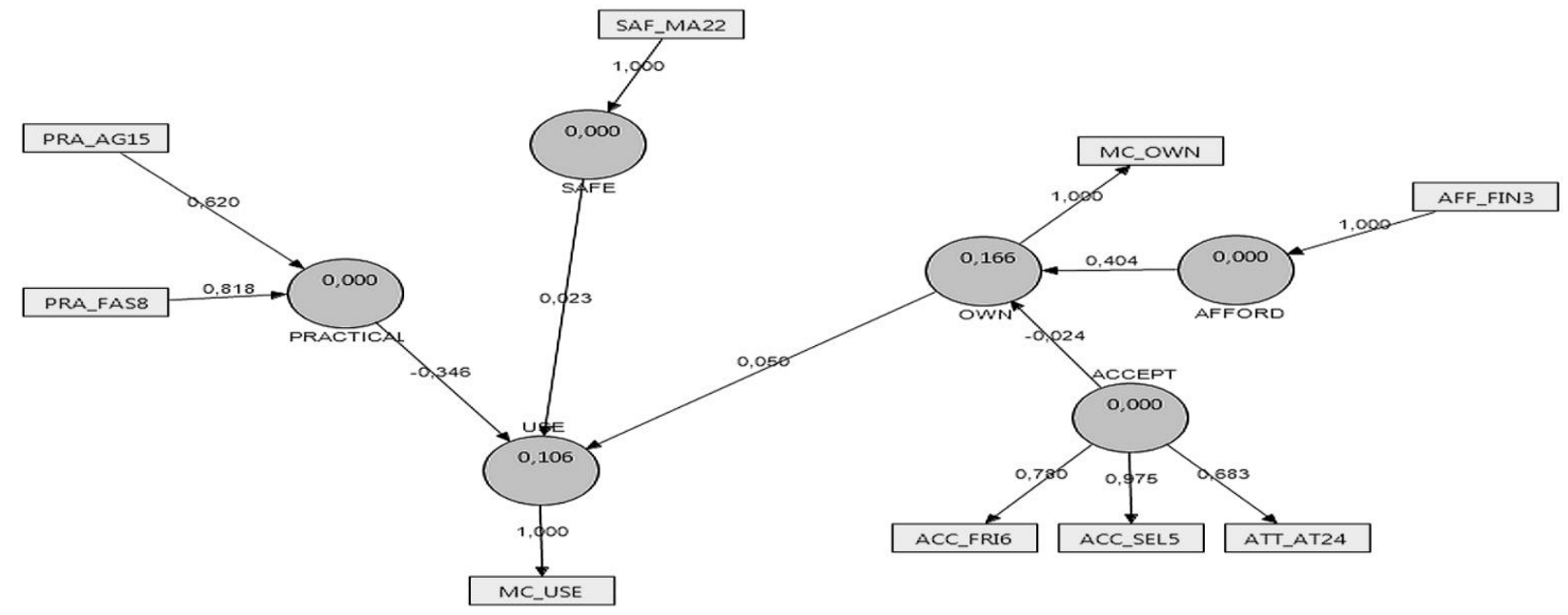

Figure 14. Smart PLS Final Model for Universitas Sriwijaya (Unsri) 


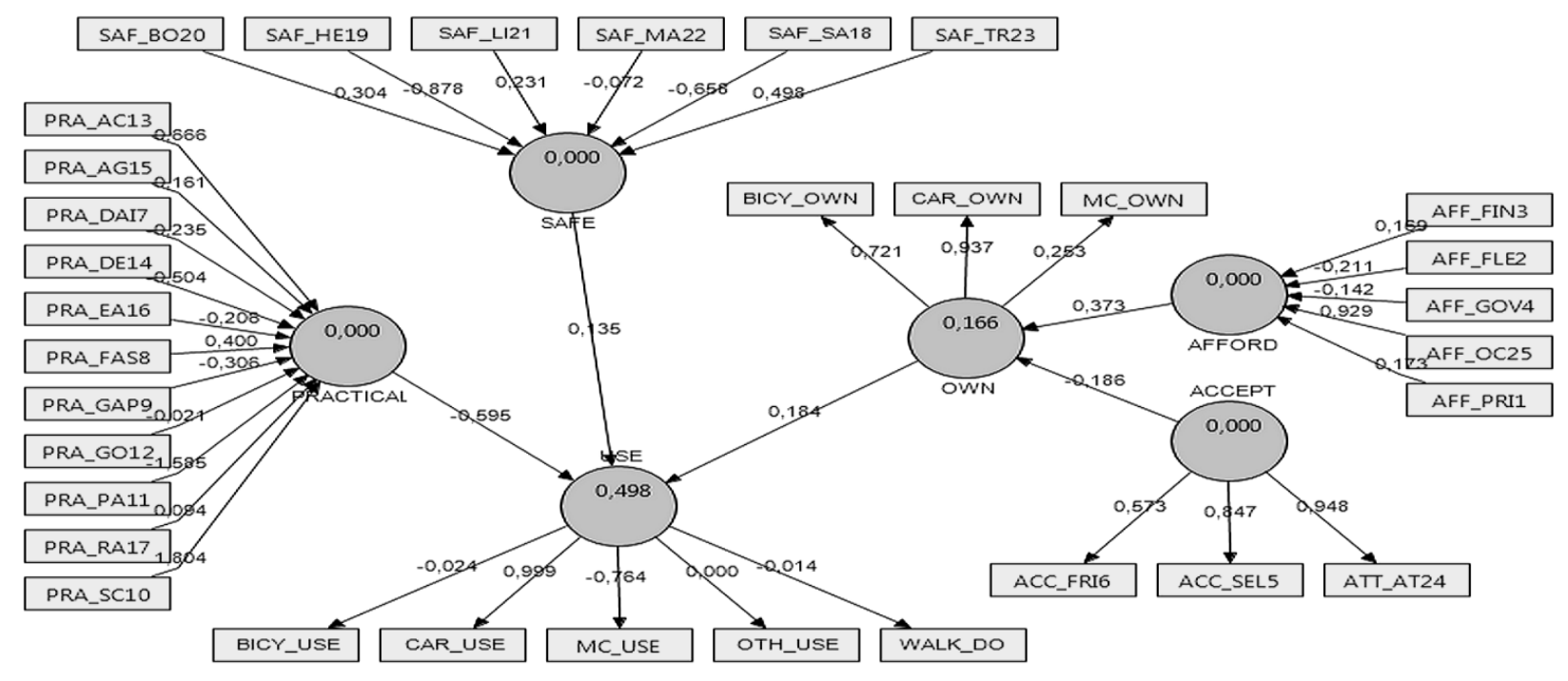

Figure 15. Smart PLS Full Model for Universitas Udayana (Unud)

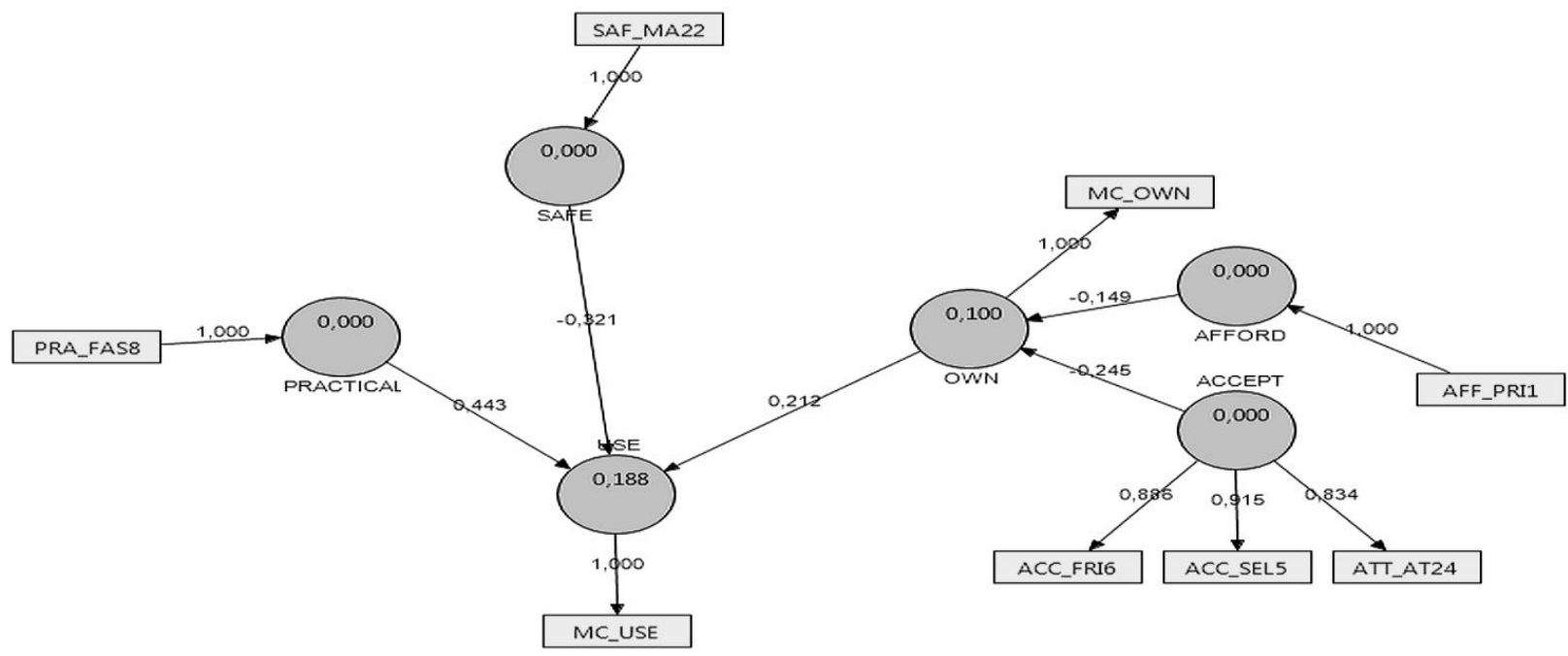

Figure 16. Smart PLS Final Model for Universitas Udayana (Unud)

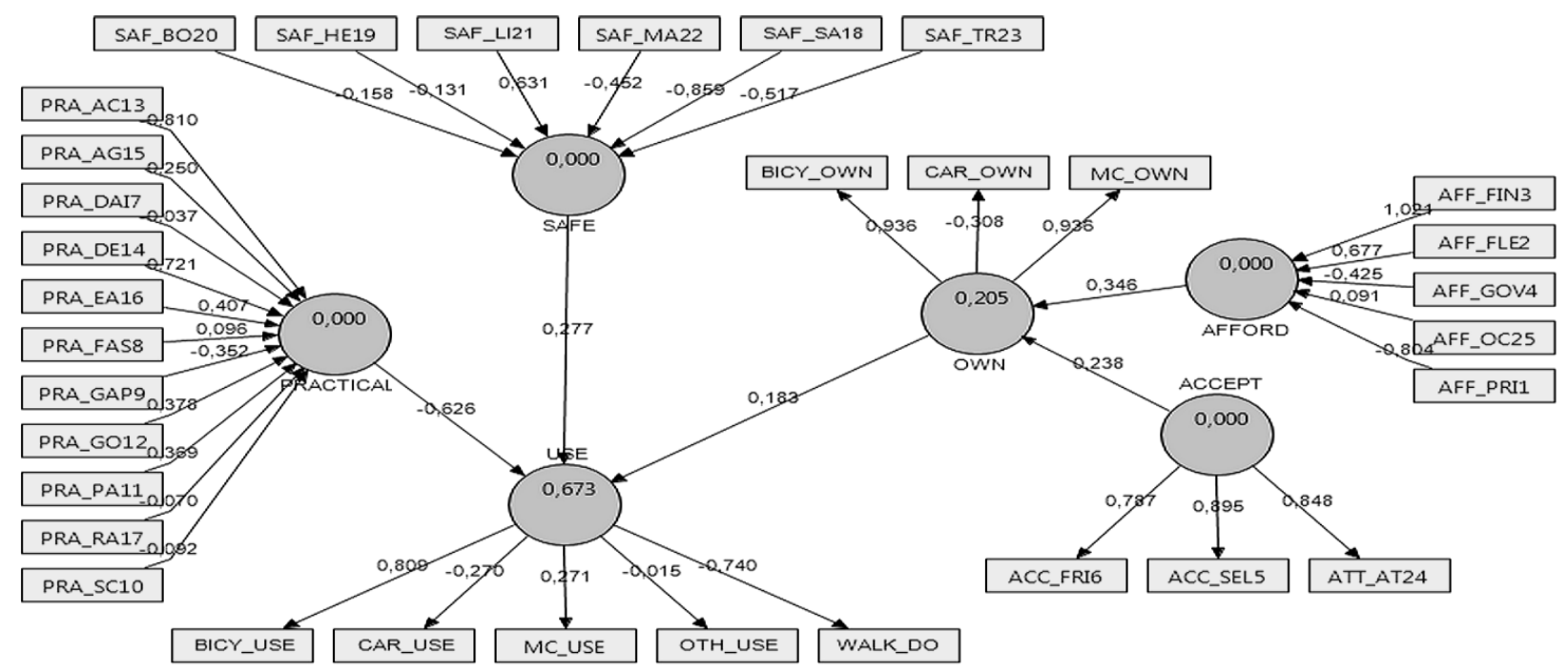

Figure 17. Smart PLS Full Model for Universiti Sains Malaysia (USM) Penang 


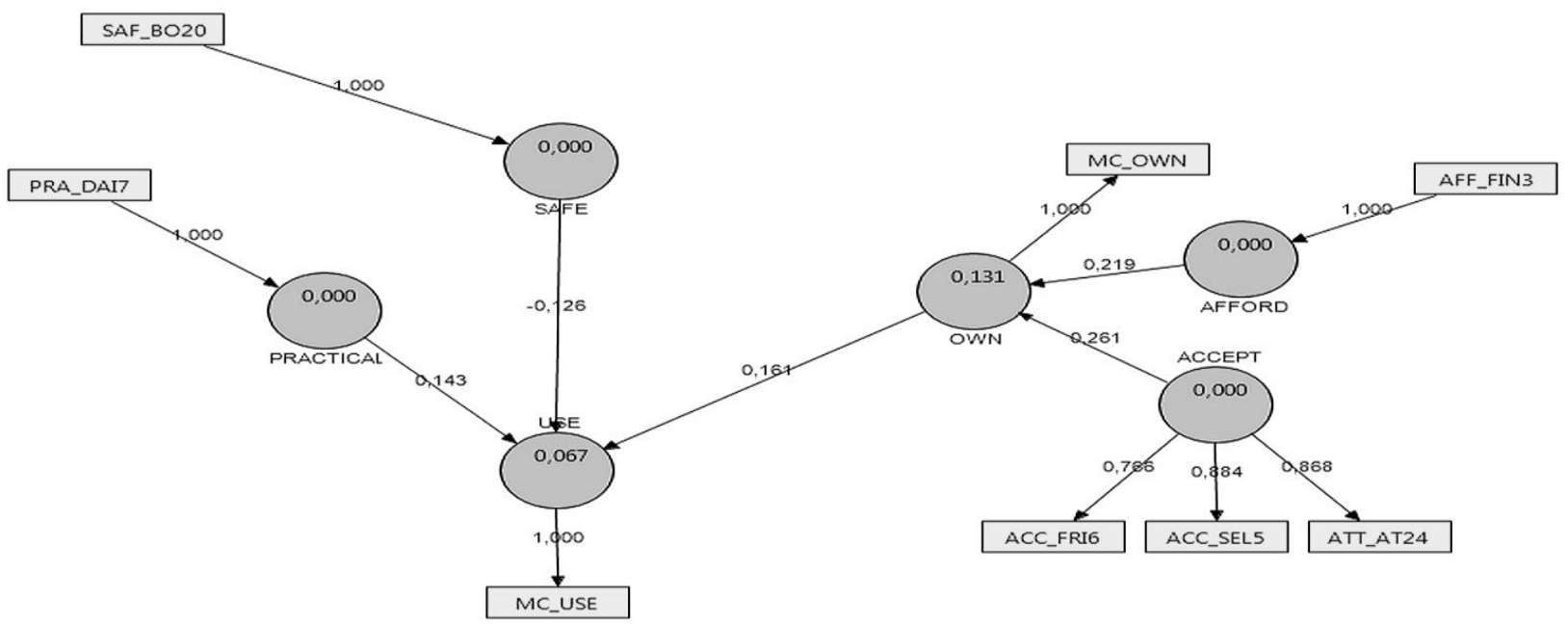

Figure 18. Smart PLS Final Model for Universiti Sains Malaysia (USM) Penang

Table 1. Summary of Indicators with SLF $>0.5$

\begin{tabular}{lclcc}
\hline \multicolumn{1}{c}{ University } & Affordability (AFF) & Acceptability (ACC) & Practicability (PRA) & Safety (SAF) \\
\hline All Ind. & FIN3 & SEL5, FRI6, ATT24 & FAS8, SC10 & HE19, BO20 \\
Itenas & GOV4, OC25 & SEL5, FRI6, ATT24 & GO12 & MA22 \\
ITS & PRI1 & SEL5, FRI6, ATT24 & FAS8, EA16 & MA22 \\
Poltek Medan & PRI1, OC25 & SEL5, FRI6 & SC10 & MA22 \\
Unram & GOV4 & SEL5, FRI6, ATT24 & SC10, PA11 & MA22 \\
Unhas & FIN3 & SEL5, FRI6 & FAS8. & BO20 \\
Unsri & FIN3 & SEL5, FRI6, ATT24 & FAS8, AG15 & MA22 \\
Unud & PRI1 & SEL5, FRI6, ATT24 & FAS8. & MA22 \\
USM & FIN3 & SEL5, FRI6, ATT24 & RA17 & BO20 \\
\hline
\end{tabular}

\section{Conclusions and Recommendations}

Based on dominant valid indicators in Table 1, the followings can be concluded,

1. Affordability of owning motorcycle can be explained by either cheap price of motorcycle or financial capability to purchase motorcycle.

2. Acceptability of owning motorcycle can be expressed by higher self-esteem, more friends and higher attractiveness of a person owning motorcycle.

3. Practicability of using motorcycle can be explained by its ability to shorten travel time during congestion, i.e. by reach travel destination faster.

4. Safety of using motorcycle can be explained by maturity (age) of the rider.

When valid indicators in combination of seven cities in Indonesia compared to valid indicators in Penang the following results are found:

1. Family financial condition is the common and the only valid indicator in affordability both in Indonesia and Malaysia

2. Self esteem improvement, number of friends increase, and attaractiveness increase are common valid indicators in acceptability.
3. In practicalibility there are no common valid indicators between Indonesia and Malaysia.

4. In safety there is only one common indicator in safety between Indonesia and Malaysia, i.e. the advantage of using bright colour outfit to increase safety

\section{References}

1. Putranto L.S, Setyarini, Prasetijo, J., and Setyarini, N.P.S.E., Vehicle Composition in Indonesian Cities and Malaysian Cities, Final Report of International Research Collaboration between Tarumanagara University and Universiti Sains Malaysia, 2012.

2. Putranto, L.S. and Tantama, C.N., Komposisi Arus Lalu-Lintas di Jalan Multi Lajur di Surabaya, Bandung dan Mataram, Prosiding Temu Ilmiah Nasional Dosen Teknik, Universitas Tarumanagara, Jakarta, Indonesia 2010, pp. $\Pi-12-\Pi-21$.

3. Departemen Pekerjaan Umum Republik Indonesia, Indonesian Highway Capacity Manual, Jakarta, Indonesia, 1997.

4. Putranto L.S and Setyarini, N.P.S.E., Vehicle Composition and Lane Distribution in Multilane Highways in Indonesian Cities, Proceeding 
of $6^{\text {th }}$ International Symposium on Highway Capacity and Quality of Services, International Road Federation, Stockholm, Sweden, 2011, pp. 374-381.

5. Putranto, L.S., Vehicle Ownership Characteristics in Indonesia, Unpublished Ph.D Thesis, Institute for Transport Studies, University of Leeds, Great Britain, 2004.

6. Kurniawan, H., Sebaran Posisi Sepeda Motor di Jalur Jalan pada Berbagai Kondisi Arus LaluLintas, Unpublished Undergraduate Thesis, Civil Engineering Department, Tarumanagara University, Jakarta, Indonesia, 2006.

7. Lin, M., Chang, S., Pai, L., and Keyl, P., A Longitudinal Study of Risk Factors for Motorcycle Crashes among Junior College Students in Taiwan, Accident Analysis and Prevention, 35 (2), 2003, pp. 243-252.

8. Tuan, V.A. and Shimizu, T., Modeling of Household Motorcycle Ownership Behaviour in Hanoi City, Journal of the Eastern Asia Society for Transport Studies, 6, 2005, pp. 1751-1765.

9. Putranto, L.S., Pramana, A., and Kurniawan, H., Hubungan antara Perilaku Pengemudi Sepeda Motor pada Berbagai Keadaan Lalulintas Jalan dengan Karakteristik Pengemudi, Kendaraan, dan Perjalanan, Jurnal Transportasi Forum Studi Transportasi Antar Perguruan Tinggi, 6(1), 2006, pp. 63-69.

10. Manan, M.M.A. and Varhelyi, A., Motorcycle Fatalities in Malaysia, International Association of Traffic and Safety Sciences Research, 36(1), 2012, pp. 30-39.
11. Chiu, W.T., Kuo, C.Y., Hung, C.C., and Chen, M., The Effect of the Taiwan Motorcycle Helmet Use Law on Head Injuries, American Journal of Public Health, 90(5), 2000, pp. 793-796.

12. Swaddhiwudhipong, W., Boonmak, C., Nguntra, P., and Mahasakpan, P., Effect of Motorcycle Rider Education on Changes in Risk Behaviours and Motorcycle-Related Injuries in Rural Thailand, Tropical Medicine and International Health, 3(10), 1998, pp. 767-770.

13. Li, L.P., Li, G.L., Cai, Q.E., Zhang, A.L., and Lo, S.K., Improper Motorcycle Helmet Use in Provincial Areas of a Developing Country, Accident Analysis and Preventation, 40(6), 2008, pp. 1937-1942.

14. French, M.T., Gumus, G., and Homer, J.F., Public Policies and Motorcycle Safety, Journal of Health Economics, 28(4), 2009, pp. 831-838.

15. Chang, H.L. and Yeh, T.H., Motorcyclist Accident Involvement by Age, Gender and Risky Behaviour in Taipei, Taiwan, Transportation Research Part F, 10(2), 2007, pp. 109-122.

16. Rosenbloom, T., Perlman, A., and Pereg, A., Hazard Perception of Motorcyclist and Car Drivers, Accident Analysis and Prevention, 43(3), 2011, pp. 601-604.

17. Wong, J.T., Chung, Y.S., and Huang, S.H., Determinants behind Young Motorcyclist' Risky Riding Behaviour, Accident Analysis and Prevention, 42(1), 2010, pp. 275-281.

18. http://www.smartpls.com/ A Primer on Partial Least Squares Structural Equation Modeling (PLS-SEM). 